\title{
Dual Activity of a Viral Lysozyme with High Efficiency for Growth Inhibition of Erwinia amylovora
}

\author{
Heike Salm and Klaus Geider
}

Max-Planck-Institut für Zellbiologie, Rosenhof, Ladenburg, Germany.

Current address of H. Salm and K. Geider: Max-Planck-Institut für Zellbiologie, c/o Biologische Bundesanstalt, Schwabenheimer Str. 101, 69221 Dossenheim, Germany.

Accepted for publication 5 August 2004.

\begin{abstract}
Salm, H., and Geider, K. 2004. Dual activity of a viral lysozyme with high efficiency for growth inhibition of Erwinia amylovora. Phytopathology 94:1315-1322.

The lysozyme from Erwinia amylovora phage $\phi E a 1 \mathrm{~h}$ was investigated for its ability to inhibit growth of bacteria and compared with the lysozyme from Escherichia coli phage T4. The assays to measure lysozyme activity included cell lysis and growth inhibition of bacteria. Bacterial strains with kanamycin resistance were not affected by lysates containing the $\phi$ Ea1h-enzyme. The titer of Micrococcus luteus but not of Erwinia

ing the T4 lysozyme activity at least one million-fold. Spherical cells were formed after application to E. amylovora similar to lyz-gene expression in Escherichia coli. Heating of cell extracts destroyed the muramidase activity, but retained an antibacterial activity. Other plant-associated bacteria related to Erwinia amylovora also were inhibited for growth when cell extracts with $\phi E a 1 h$ lysozyme were applied to soak pear slices and potato slices. Ooze formation and soft rot caused by E. amylovora or E. carotovora subsp. atroseptica, respectively, were strongly reduced and the $\phi E a 1 h$ lysozyme was more efficient compared with extracts containing T4 lysozyme.
\end{abstract} amylovora was diminished by cell extracts containing T4 lysozyme. In contrast, $\phi$ Ea1h lysozyme preferentially inhibited E. amylovora, exceed-
Additional keyword: fire blight.
Fire blight on apple and pear is caused by Erwinia amylovora and is responsible for severe losses in fruit production in many countries of the northern hemisphere and in New Zealand (30). The antibiotic streptomycin is used for effective management of fire blight, but spraying is not allowed in many countries with occurrence of the disease. Recent biological control agents such as the Pseudomonas fluorescens strain A506 have been applied (21) and bacteriophages have been characterized for their possible use in fire blight control (28). Plant-resistance inducers such as Prohexadione-Ca (Regalis and Apogee) (3) and benzo (1-3) thiadiazol-7-carbothioacid-S-methyl ester (BTH; the active component of BION) (2) act inside the plant, which requires application well before possible fire blight infections. Transgenic apple and pear plants expressing the antimicrobial protein attacin E (24) or the exopolysaccharide (EPS) depolymerase from the bacteriophage $\phi E a 1 h$ (11) resulted in an increase of resistance against fire blight. Attacin E originating from Hyalophora cecropia has an antibacterial activity directed against the outer membrane of bacteria (5), but may confer general hemolytic properties. Also, lysozymes have a potential as antimicrobial proteins. These are synthesized late in the lytic life cycle of the bacteriophages to lyze the host cell, but are not packed into the viral capside. The enzymatic activity of lysozyme hydrolyzes the glycosidic $\beta$-linkage between the $N$-acetylglucosamine and the $N$-acetylmuramic acid of the peptidoglycan layer in the bacterial cell wall. An additional activity affecting bacterial growth was characterized for T4 and hen egg white (HEW) lysozyme $(8,13,14)$. Inactivation of the lytic ac-

Corresponding author: K. Geider; E-mail address: K.Geider@bba.de

* The $\boldsymbol{e}$-Xtra logo stands for "electronic extra" and indicates that the online version contains supplemental material not included in the print edition. Figure 3 is in color online.

Publication no. P-2004-0923-01R

(C) 2004 The American Phytopathological Society tivity by boiling or mutagenesis did not abolish a bactericidal property interfering with bacterial membrane functions. On the other hand, the effect of T4 lysozyme on bacterial viability was much more pronounced for gram-positive bacteria than for gramnegative bacteria, except for Xanthomonas campestris (6). The lysozyme gene of Escherichia coli bacteriophage T4 also was transformed to increase resistance of apple against Erwinia amylovora $(10,20)$ and of potatoes against the soft rot bacterium E. carotovora $(7,25)$. The expressed protein had a marginal effect on pathogen control. In this study, we show an activity of the lysozyme from E. amylovora phage $\phi E a 1$ h against E. amylovora strains and other plant-associated gram-negative bacteria superior to that of T4 lysozyme.

\section{MATERIALS AND METHODS}

Bacterial strains and plasmids. The strains predominantly used for expression of $l y z$ and for assays of bactericidal activities of the protein are listed in Table 1. Plasmid pREP4 with a mini 15 origin for replication expresses high levels of the lac-repressor, turning off the lac-promoter in pQE30 with the inserted lyz gene.

Cloning of lysozyme genes. The $\phi E a 1 h$ lysozyme gene (EMBL Nucleotide Sequence Database accession no. AJ278614) was cloned previously from plasmid pJH94 into vector pQE30 (19).

The T4 lysozyme gene was amplified by polymerase chain reaction (PCR) from T4 DNA as template. The primers were designed from the nucleotide sequence of the T4 genome (gene " $e$ ": nucleotides 66503...66997; accession number AF158101 in the EMBL Nucleotide Sequence Database). The forward primer T4LYZ1 (5'-CTTAGGAGGTATTATGA, containing a ribosome binding site and a start codon) and the reverse primer T4LYZ2c (5'-TTATAGATTTTTATACGCGTCCC) were used in PCR using conditions described before (17), and the resulting amplification product was cloned directly into pGEMT. The created plasmid 
pGEMT-T4lyz was transformed into Escherichia coli strain M15(pREP4).

Preparation and heat denaturation of lysozyme. To express the cloned lysozyme genes in E. coli M15(pREP4, pQE-lyz1) and M15(pREP4, pGEMT-T4lyz), the strains were cultured at $37^{\circ} \mathrm{C}$ in $400 \mathrm{ml}$ of Luria-Bertani broth (LB medium) with ampicillin $(100 \mu \mathrm{g} / \mathrm{ml})$ and kanamycin $(20 \mu \mathrm{g} / \mathrm{ml})$ to an optical density at $600 \mathrm{~nm}\left(\mathrm{OD}_{600}\right)$ of 0.5 . The cultures were induced with $1 \mathrm{mM}$ isopropyl- $\beta$-D-thiogalactopyranoside (IPTG) and further incubated for $1 \mathrm{~h}$ without shaking. The cultures were centrifuged at $4,000 \times g$ for $20 \mathrm{~min}$, and the pellets were suspended in $2.5 \mathrm{ml}$ of buffer $\left(0.3 \mathrm{M} \mathrm{NaCl}, 50 \mathrm{mM} \mathrm{NaH}_{2} \mathrm{PO}_{4}, \mathrm{pH} 8.0\right)$ containing $10 \mathrm{mM}$ imidazol recommended for binding of His-fusion proteins to Nicolumns. After sonication, a clear cell lysate was obtained by centrifugation at $10,000 \times g$ for $20 \mathrm{~min}$. Due to the lack of binding of the Lyz-His-fusion protein to the Ni-residues (19), cell extracts were used in the experiments.

For heat inactivation the cell lysate from M15(pREP4, pQElyz1) with $\phi E a 1 \mathrm{~h}$, lysozyme was boiled for 5 to $60 \mathrm{~min}$. Denatured protein was removed by centrifugation $(\approx 50 \%$ of the total protein), and the cleared supernatant was screened for muramidase activity and bactericidal activity as described below. The protein concentration was measured by the method of Lowry et al. (22).

Plate growth inhibition assay. The lysozyme activity and the sensitivity of strains to lysozyme (Table 2) were screened by growth inhibition on a lawn of indicator cells. Overnight cultures of the indicator strains $(50 \mu \mathrm{l})$ were mixed with $3 \mathrm{ml}$ of soft agar (LB broth containing $0.4 \%$ agar) and spread on the surface of LB plates. Finally, $10 \mu \mathrm{l}$ of the cell lysate containing lysozyme was dropped onto the surface, and the plates were incubated overnight at $28^{\circ} \mathrm{C}$ in case of plant-pathogenic strains and at $37^{\circ} \mathrm{C}$ for E. coli strains. Zones of inhibition were measured for intensity.

Microtiter assays. Lysozyme activity was assayed with Erwinia amylovora Ea1/79Sm or other indicator strains grown overnight at $28^{\circ} \mathrm{C}$ in Standard I (StI; Merck AG, Darmstadt, Germany) medium supplemented with an antibiotic when indicated. Dilutions of the cells $\left(5 \times 10^{3} \mathrm{CFU} / \mathrm{ml}\right)$ were dispensed in microtiter plates $(200 \mu \mathrm{l}$ per well). The native or heat-denatured lysates were added ( $320 \mu \mathrm{g}$ of total protein), and the microwell cultures were further incubated by shaking at $140 \mathrm{rpm}$ and $28^{\circ} \mathrm{C}$. As negative control, lysate from M15(pREP4, pQE-30) was applied. The influence of the cell lysates was monitored via the bacterial growth rate by automatic $\mathrm{OD}_{620}$ measurements with a Titertek Multiskan MCC/ 340 MKII (Flow Laboratories International SA, Switzerland).

Muramidase activity assays. The substrate cells of E. amylovora and Micrococcus luteus were prepared from an overnight culture in StI, and the bacteria were lyophilized by Speed Vac centrifugation. The cell pellet was resuspended in $10 \mathrm{mM}$ potassium phosphate buffer $\mathrm{pH} 8.0$ and adjusted to an $\mathrm{OD}_{450}$ of 0.6 to 0.7 . The decrease in turbidity of the cell suspension was monitored in a volume of $500 \mu \mathrm{l}$ after the addition of $200 \mu \mathrm{g}$ of protein from a cell lysate containing $\phi$ Ea1h lysozyme.

Determination of viable cells. The indicator strains Ea1/79 and M. luteus were grown overnight in LB broth, diluted, and further cultured to an $\mathrm{OD}_{600}$ of 0.3 . The cells of a 2-ml culture were harvested by centrifugation, washed twice with $0.1 \times$ phosphatebuffered saline (PBS) buffer, and resuspended in $20 \mathrm{ml}$ of buffer. The cleared lysates containing lysozyme were added to $200 \mu \mathrm{l}$ of cell suspensions and the cells were incubated with shaking for $2 \mathrm{~h}$ at $28^{\circ} \mathrm{C}$. For control, $0.1 \times$ PBS buffer was added to the cells. After incubation, several dilutions were plated on LB agar and incubated for 2 days at $28^{\circ} \mathrm{C}$. Cell lysates containing T4 or $\phi$ Ea1h lysozyme were first titered for optimal inhibition of $M$. luteus. Typically, $300 \mu \mathrm{g}$ of protein from cell extracts containing $\phi E a 1 \mathrm{~h}$ lysozyme or $36 \mu \mathrm{g}$ of protein from cell extracts with T4 lysozyme were applied to E. amylovora.

Preparation of spheroplasts and staining assay. The E. amylovora strain Ea1/79 was cultured overnight at $28^{\circ} \mathrm{C}$ in LB broth. After dilution, the cells were further shaken to reach an $\mathrm{OD}_{600}$ of $\approx 0.3$. The cells $(8 \mathrm{ml})$ were harvested by centrifugation, and the pellet was resuspended in $7 \mathrm{ml}$ of LB broth containing sucrose (1\%), bovine serum albumen (BSA) $(0.05 \%)$, EDTA $(0.36 \mathrm{mM})$, and cell extract with lysozyme. The cells were incubated for $15 \mathrm{~min}$ at room temperature, and the reaction was stopped by addition of $100 \mu \mathrm{l}$ of $1 \mathrm{M} \mathrm{MgSO}_{4}$. The cultures $(10 \mu \mathrm{l})$ were stained with $1 \mu \mathrm{l}$ of a $1: 1$ mixture of components $\mathrm{A}$ and $\mathrm{B}$ of the LIVE/DEAD BacLight Bacterial Viability Kit (Molecular Probes, Eugene, OR). The stained bacteria were visualized with the Zeiss Axiophot fluorescence microscope S100 (Carl Zeiss, Oberkochem, Germany) using the filter combination 450-490/FT510/ 515-565 (excitation filter dichroic-emission filter) for green fluorescence and BP546/FT580/LP590 for red fluorescence.

Virulence tests on pear and potato slices. Immature pear slices (cv. Bartlett, 2 to $3 \mathrm{~cm}$ in diameter) were soaked with cleared lysates of Escherichia coli strains M15(pREP4, pQElyz1), M15(pREP4, pGEMT-T4lyz), or M15(pREP4, pQE-30) as negative control for $1 \mathrm{~h}$ in a petri dish and air dried. Various amounts of Erwinia amylovora strain Ea1/79 in 10- $\mu$ l drops were applied to the surface and the pear slices were incubated in airtight plastic boxes at $27^{\circ} \mathrm{C}$. Symptoms were evaluated 1 week after inoculation on a scale of 0 (no symptoms) to 4 (ooze in large drops or as a fluidal layer on the surface) as described previously (17). The test system was modified to check the effect of $\phi E a 1 h$

TABLE 1. Bacterial strains and plasmids used

\begin{tabular}{|c|c|c|}
\hline Strains, plasmids & Phenotype, relevant characteristics & Source, reference \\
\hline \multicolumn{3}{|l|}{ Bacterial strains } \\
\hline \multicolumn{3}{|l|}{ Escherichia coli } \\
\hline M15 & $\mathrm{Str}^{\mathrm{R}}, \mathrm{F}^{-}, \Delta l a c \mathrm{Z}$ & QIAGEN \\
\hline $\mathrm{Ea} 1 / 79$ & Isolated from Cotoneaster sp., Germany, 1979 & 9 \\
\hline $\mathrm{Ea} 1 / 79 \mathrm{Sm}$ & $\mathrm{Sm}^{\mathrm{R}}$ on chromosome of strain Ea1/79 & Lab collection \\
\hline \multicolumn{3}{|c|}{ E. carotovora subsp. atroseptica } \\
\hline Eca185 & Wild type & Lab collection \\
\hline Ejp557 & Erwinia sp. from Japan & 18 \\
\hline Micrococcus luteus & Wild type & Lab collection \\
\hline \multicolumn{3}{|l|}{ Plasmids } \\
\hline pGEMT & $\mathrm{Ap}^{\mathrm{R}}$, for cloning of polymerase chain reaction fragments & Promega \\
\hline pGEMT-T4lyz & $\mathrm{Ap}^{\mathrm{R}}$, with insertion of lyz gene from phage $\mathrm{T} 4$ & This work \\
\hline pJH94 & $\mathrm{Ap}^{\mathrm{R}}, 3.3$-kb insertion after a partial Sau $3 A$ digest of DNA from phage $\phi E a 1 \mathrm{~h}$ in $\mathrm{pUC} 8$ & 12 \\
\hline pREP4 & ori mini 15 , lacI ${ }^{\mathrm{q}}, \mathrm{Km}^{\mathrm{R}}$ & QIAGEN \\
\hline
\end{tabular}


lysozyme and T4 lysozyme on soft rot bacterium Eca185 on potatoes. Potato tubers (organically grown and untreated) were peeled, sliced into pieces $\approx 1 \mathrm{~cm}^{2}$ in size, and soaked in the lysates as described for pear slices. The E. carotovora subsp. atroseptica cells from diluted overnight cultures were applied in 5 - $\mu$ l drops to the surface, and the potato slices were incubated for 1 day at $28^{\circ} \mathrm{C}$ in air-tight plastic boxes. The symptoms were rated on a scale of 0 (no symptoms) to 3 (most of the potato surface soft and colored brown to black).

\section{RESULTS}

Lysozyme expression in Escherichia coli. The toxicity of $\phi E a 1 h$ lysozyme for Escherichia coli cells first was noticed when cloning DNA fragments with the encoding gene. In contrast to the T4 lysozyme gene, the $\phi \mathrm{Ea} 1 \mathrm{~h}$ lysozyme gene was difficult to clone in E. coli and to express in the bacterial host. The growth profiles of $E$. coli strains M15(pREP4, pQE-lyz1) and M15(pREP4, pQE-30) in LB medium with antibiotics before and after addition of IPTG are shown in Figure 1A. Plasmid pREP4 with a constitutive expression of the lac repressor is important to suppress the lac-promoter in the pQE-plasmids in the absence of IPTG to avoid cell damage by lysozyme. The induction of lysozyme expression in strain M15(pREP4, pQE-lyz1) resulted in a cessation of cell growth and a decrease of absorbance at $600 \mathrm{~nm}$, typical for cell lysis. No difference was found for M15(pREP4, pQE-30) in cell growth after addition of IPTG or in cultures without IPTG. These results indicated that the expression of $\phi E a 1 \mathrm{~h}$ lysozyme is extremely toxic for the cells. For induced but not for uninduced $E$. coli cells harboring the T4 lysozyme gene, an arrest (sometimes delayed) of cell growth but no cell lysis symptoms were observed after induction of T4 lysozyme expression (Fig. 1B). Compared with $\phi E a 1 h$ lysozyme, T4 lysozyme showed a lower toxicity to the $E$. coli host cells. In amino acid alignments, the two proteins were related in the region attributed to catalytic activity (27), but the complete alignment of the amino acid sequences revealed a similarity of only $18 \%$ (data not shown). Thus, different properties can be expected for the two proteins.

Changes in cell morphology of E. coli strain M15(pREP4, pQE-lyz1) were monitored with the fluorescence microscope. Samples of the culture before and after addition of IPTG were taken, stained with the LIVE/DEAD BacLight kit, and analyzed microscopically. One hour after lysozyme induction, the morphology switched from rod-shaped cells to spheroplasts, the membrane permeability was disturbed, and the cells started to die, as indicated by a color change from green to red (data not shown).

Muramidase activity and formation of spheroplasts. The enzymatic activity of lysozyme was measured in a photometric assay by a decrease of the $\mathrm{OD}_{450}$ with previously lyophilized bacteria as substrate. Muramidase activity was found for native $\phi \mathrm{Ea} 1 \mathrm{~h}$ lysozyme with Ea1/79 cells (Fig. 2). The activity decreased in phosphate buffer below $\mathrm{pH} 8$ (data not shown). No change in turbidity and, consequently, no enzymatic activity was detected for $\phi E a 1 h$ lysozyme containing extracts which were heat denatured for 5 to $60 \mathrm{~min}$, and for a cell lysate from M15(pREP4, pQE-30) as a control without lysozyme. When lyophilized cells from $M$. luteus were used as substrate for native $\phi E a 1 \mathrm{~h}$ lysozyme, no decline of turbidity was observed, indicating a low level of lytic activity against lyophilized gram-positive bacterial cells (Fig. 2).

The muramidase activity was further monitored microscopically with the cell lysate of M15(pREP4, pQE-lyz1) as the enzyme source and Erwinia amylovora cells stained with the LIVE/DEAD BacLight kit. The cell pellets of E. amylovora were suspended in a solution with BSA, lysozyme, EDTA, and sucrose. After a short incubation, the cell morphology changed from rodshaped to spherical (Fig. 3B). Heat denaturation of the cell lysate containing $\phi$ Ealh lysozyme resulted in a loss of the enzymatic function, and all bacteria remained rod-shaped (Fig. 3A and C).
TABLE 2. Reaction of bacterial strains to $\phi E a 1 h-l y s o z y m e$

\begin{tabular}{|c|c|c|}
\hline Strain $^{a}$ & Relevant characteristics & Reaction $^{\mathrm{b}}$ \\
\hline \multicolumn{3}{|l|}{ Erwinia amylovora } \\
\hline CFBP1430 & wt, France & + \\
\hline $\mathrm{Ea} 7 / 74$ & wt, Germany & + \\
\hline $\mathrm{Ea} 1 / 79$ & wt, Germany & + \\
\hline $\mathrm{Ea} 1 / 79 \mathrm{Sm}$ & $\mathrm{Ea} 1 / 79, \mathrm{Sm}^{\mathrm{R}}$ & + \\
\hline Ea1/79(pfdC1Z'-lux) & $\mathrm{Km}^{\mathrm{R}}, n p t \mathrm{I}$ on plasmid & - \\
\hline $\mathrm{Ea} 266$ & wt, Germany & + \\
\hline $\mathrm{Ea} 296$ & wt, Austria & + \\
\hline Ea321 & wt, France & + \\
\hline Ea322 & wt, France & + \\
\hline EaU8/96 & wt, United States & + \\
\hline Ea1/79-D4 & $\operatorname{ams} \mathrm{E} ; \mathrm{Km}^{\mathrm{R}}$ & - \\
\hline Ea1/79-D12 & $\operatorname{amsC} ; \mathrm{Km}^{\mathrm{R}}$ & - \\
\hline Ea1/79-D26 & amsF; $\mathrm{Km}^{\mathrm{R}}$ & - \\
\hline Ea1/79-D32 & $\operatorname{ams} \mathrm{B} ; \mathrm{Km}^{\mathrm{R}}$ & - \\
\hline Ea1/79-D41 & $a m s \mathrm{E} ; \mathrm{Km}^{\mathrm{R}}$ & - \\
\hline Ea1/79-D41(pEA109) & $\operatorname{ams} \mathrm{E} ; \mathrm{Km}^{\mathrm{R}}, \mathrm{Tc}^{\mathrm{R}}$ & - \\
\hline Ea1/79-D49 & $\operatorname{ams} \mathrm{A} ; \mathrm{Km}^{\mathrm{R}}$ & - \\
\hline Ea1/79-D50 & $\operatorname{ams} \mathrm{D} ; \mathrm{Km}^{\mathrm{R}}$ & - \\
\hline Ea1/79-del100 & $\Delta$ ams $\mathrm{A}-\mathrm{J} ; \mathrm{Cm}^{\mathrm{R}}$ & + \\
\hline Ea1/79-del100(pEA109) & $\mathrm{Cm}^{\mathrm{R}}, \mathrm{Tc}^{\mathrm{R}}$ & + \\
\hline $\mathrm{Ea} 1 / 79-\mathrm{K} 13 \mathrm{~A}$ & 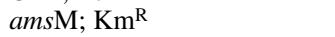 & - \\
\hline Ea1/79-M1 & $\operatorname{gal} \mathrm{E}, \mathrm{Km}^{\mathrm{R}}$ & - \\
\hline Ea1-M34B & ams $\mathrm{M} ; \mathrm{Ap}^{\mathrm{R}}$ & + \\
\hline Ea1/79MV26 & $\operatorname{rcs} \mathrm{V}, \mathrm{Km}^{\mathrm{R}}$ & - \\
\hline Ea1/79Suc3 & $\operatorname{scr} \mathrm{A} ; \mathrm{Km}^{\mathrm{R}}$ & - \\
\hline Ea7/74-1(Tn5) & Random Tn5 insertion, $\mathrm{Km}^{\mathrm{R}}$ & - \\
\hline $\mathrm{Ea} 7 / 74-\mathrm{A} 83$ & ams; $\mathrm{Km}^{\mathrm{R}}$ & - \\
\hline Ea7/74-S64 & Leucin deficient; $\mathrm{Km}^{\mathrm{R}}$ & - \\
\hline Ea7/74-LS6 & $l s c ; \mathrm{Km}^{\mathrm{R}}$ & - \\
\hline $\mathrm{Ea} 7 / 74-\mathrm{A} 72$ & $d s p ; \mathrm{Km}^{\mathrm{R}}$ & - \\
\hline $\mathrm{Ea} 7 / 74-\mathrm{K} 17$ & ams $\mathrm{L} ; \mathrm{Km}^{\mathrm{R}}$ & - \\
\hline Ea7/74-K17(pEA109) & ams L complemented; $\mathrm{Km}^{\mathrm{R}}$ & - \\
\hline Ea7/74-S14 & $s r l ; \mathrm{Km}^{\mathrm{R}}$ & - \\
\hline $\mathrm{EaX} 7 / 74$ & plasmid free (-pEA29) & + \\
\hline Ea153Nal & $\mathrm{Nal}^{\mathrm{R}}$; United States & + \\
\hline Ea321-T103 & $\mathrm{Eps}^{-} ; \mathrm{Km}^{\mathrm{R}}$ & - \\
\hline Ea321-T120 & $\mathrm{Eps}^{-} ; \mathrm{Tc}^{\mathrm{R}}$ & + \\
\hline Ea322-T110 & $\mathrm{Eps}^{-} ; \mathrm{Km}^{\mathrm{R}}$ & - \\
\hline Ea322-T177 & $\mathrm{Eps}^{-} ; \mathrm{Km}^{\mathrm{R}}$ & - \\
\hline Ea322A & $h r p ; \mathrm{Km}^{\mathrm{R}}$ & - \\
\hline PD350Sm & Levan-deficient, $\mathrm{Sm}^{\mathrm{R}}$ & + \\
\hline PMV6023 & $h r p ; \mathrm{Cm}^{\mathrm{R}}$ & + \\
\hline PMV6046 & hrp $; \mathrm{Cm}^{\mathrm{R}}$ & + \\
\hline PMV6059 & $d s p ; \mathrm{Cm}^{\mathrm{R}}$ & + \\
\hline PMV6069 & $d s p ; \mathrm{Cm}^{\mathrm{R}}$ & + \\
\hline PMV6076 & hrp $; \mathrm{Cm}^{\mathrm{R}}$ & + \\
\hline PMV6076-D4 & hrp, amsE; $\mathrm{Cm}^{\mathrm{R}}, \mathrm{Km}^{\mathrm{R}}$ & - \\
\hline PMV6089 & ams; $\mathrm{Cm}^{\mathrm{R}}$ & + \\
\hline PMV6191 & ams; $\mathrm{Km}^{\mathrm{R}}$ & - \\
\hline PMV6222 & $a m s ; \mathrm{Km}^{\mathrm{R}}$ & - \\
\hline $\mathrm{Ea} 3250$ & Synonym "P66", hrp & + \\
\hline $\mathrm{Ea} 3251$ & Synonym “S”, galE & + \\
\hline \multicolumn{3}{|l|}{ E. pyrifoliae } \\
\hline Ep1/96 & wt, Korea & + \\
\hline Ep2/97 & wt, Korea & + \\
\hline Ep1/96mB & cpsB; $\mathrm{Cm}^{\mathrm{R}}$ & + \\
\hline Ep2/97(pGThrpLEp:Ep2) & $h r p ; \mathrm{Ap}^{\mathrm{R}}$ & + \\
\hline Ep2/97(pGThrpLEp:Ep2) & $h r p ; \mathrm{Ap}^{\mathrm{R}}$ & + \\
\hline \multicolumn{3}{|l|}{ Japanese Erwinia** } \\
\hline Ejp546 & wt, Japan & + \\
\hline Ejp557 & wt, Japan & + \\
\hline \multicolumn{3}{|c|}{ E. carotovora subsp. atroseptica } \\
\hline Eca 185 & wt, Germany & + \\
\hline \multicolumn{3}{|l|}{ Pantoea agglomerans } \\
\hline EhNZ & wt, New Zealand & + \\
\hline EhA1 & wt, England & + \\
\hline \multicolumn{3}{|l|}{ Escherichia coli } \\
\hline Ec1100 & wt & + \\
\hline M15(pREP4) & $\mathrm{Km}^{\mathrm{R}}$ & - \\
\hline HB101(pRK2013::Tn7) & $\mathrm{Tp}^{\mathrm{R}}, \mathrm{Sp}^{\mathrm{R}}, \mathrm{Sm}^{\mathrm{R} *}$ on $\mathrm{Tn} 7$ & + \\
\hline
\end{tabular}

${ }^{a}$ Strains and mutants have been described further in previous papers of the lab $(1,3,4,9,26)$. Strains with the designation PMV were provided by J. Laurent, INRA, Paris; Ea322A, Ea321, and derivatives were obtained from S. Beer, Cornell University, Ithaca, NY. In most cases, $\mathrm{Km}^{\mathrm{R}}$ was expressed from Tn5 (nptII); the nptI gene was carried on pfdC1Z'-lux and pREP4. * Indicates low $\mathrm{Sm}$ resistance caused by streptomycin phosphotransferase gene on $\mathrm{Tn} 7$; $\mathrm{Tp}=$ trimethoprim; $* *=$ pear pathogens described by Kim et al. (18).

b Sensitivity to $\phi$ Ealh lysozyme present (+) or absent (-). 
Nonviable E. amylovora rarely were detected in this staining procedure. Presumably, these cells quickly lysed after damage of the membrane. Formation of concatenated cells (Fig. 3C) indicated membrane disturbance. In a similar experiment with cell

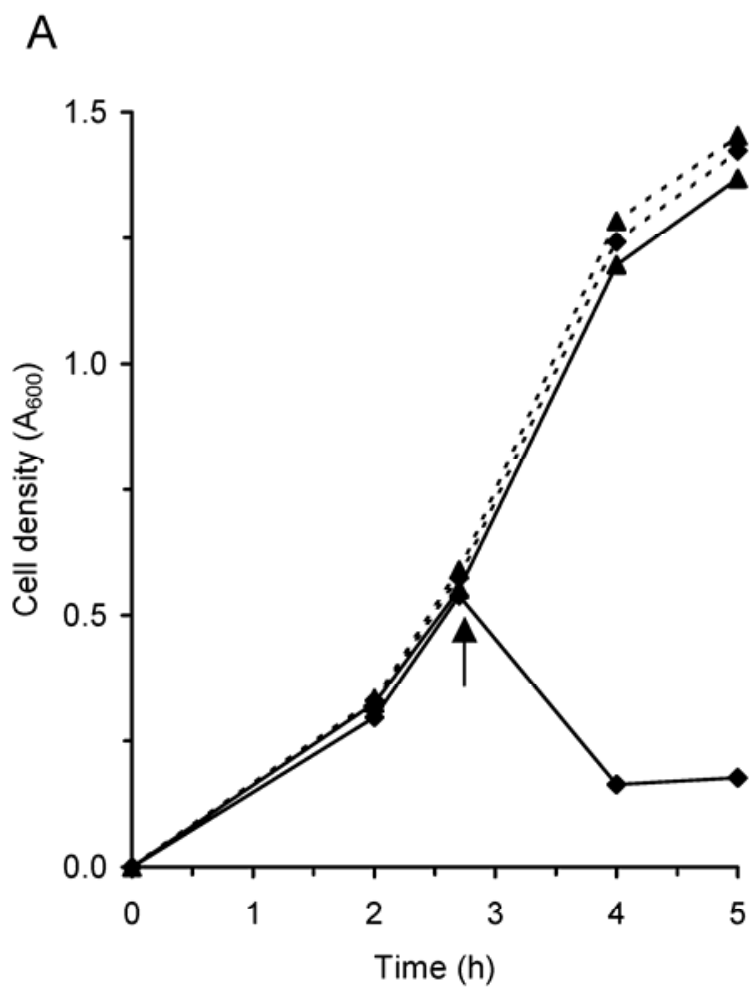

B

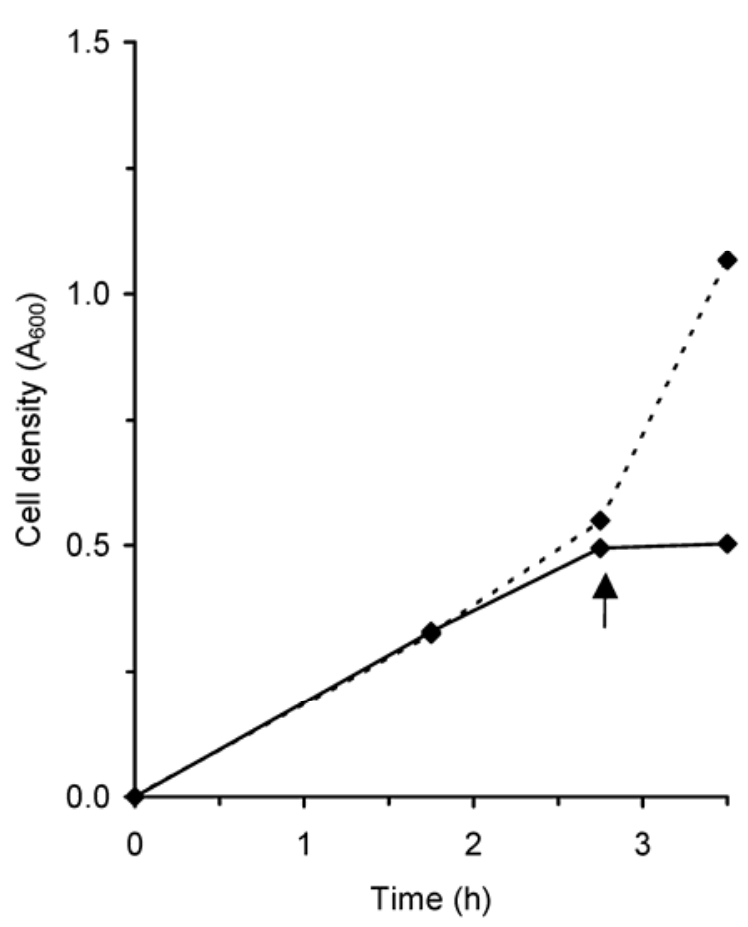

Fig. 1. Effect of lysozyme expression on growth of Escherichia coli in LuriaBertani broth with kanamycin and ampicillin at $37^{\circ} \mathrm{C}$. A, Growth curves of M15(pREP4, pQE-lyz1) with ( $)$ or without $(\boldsymbol{\Delta})$ addition of isopropyl- $\beta$-Dthiogalactopyranoside (IPTG; solid lines) and M15(pREP4, pQE-30) with ( $)$ or without ( $\mathbf{\Delta})$ addition of IPTG (dotted lines). B, Growth curves of M15(pREP4, pGEMT-T4) with (solid line) and without (dotted line) addition of IPTG. The arrows indicate the time point of IPTG addition. lysates of M15(pREP4, pGEMT-T4lyz), formation of spheroplasts was observed (data not shown), indicating muraminidase activity of the protein extracts with T4 lysozyme.

Antibacterial activity. After short or prolonged heat inactivation, the cell lysate with $\phi E a 1 \mathrm{~h}$ lysozyme still inhibited growth of bacteria in a lawn on agar (Fig. 4). Accordingly, the antibacterial activity of lysozyme did not depend on a native protein conformation and was independent of an enzymatic function.

The inhibition by native and heat-denatured lysozyme was compared in a growth assay using microtiter plates. E. amylovora Ea1/79Sm was used as indicator, and the same amount of total protein from untreated M15(pREP4, pQE-lyz1) cell lysate and heat-treated cell lysate was added to Ea1/79Sm cultures (Fig. 5). Samples containing the native lysozyme showed a delay in cell growth for $24 \mathrm{~h}$. No growth was detected for the cells incubated with heat-denatured $\phi E a 1 h$ lysozyme. Thus, the inhibition was stronger for the denatured protein than for the same amount of native protein. This effect also was found when the same volume of denatured protein was added, indicating an increase of inhibiting capacity by denaturation.

Bacterial strains affected by the enzyme. For the fire blight pathogen E. amylovora, several wild-type strains and mutants were screened in an inhibition assay for response to the $\phi E a 1 \mathrm{~h} l y-$ sozyme. Most of the E. amylovora strains were isolated in Europe, and a few in North America (Ea153 and EaU8/96). In agreement with the high relatedness of E. amylovora strains, many tested strains were sensitive to $\phi E a 1 h$ lysozyme. Mutants were defective in the EPS-encoding region (ams), in pathogenicity related genes $(h r p / d s p)$, and in genes for sugar metabolism ( $\mathrm{gal}$ and $\mathrm{srl}$ ). Additional strains were defective in leucin metabolism and the synthesis of levan. Some of the mutants were complemented with the intact gene. None of the mutated genes affected the sensitivity to $\phi E a 1 \mathrm{~h}$ lysozyme, with the major exception that all strains expressing kanamycin resistance were insensi-

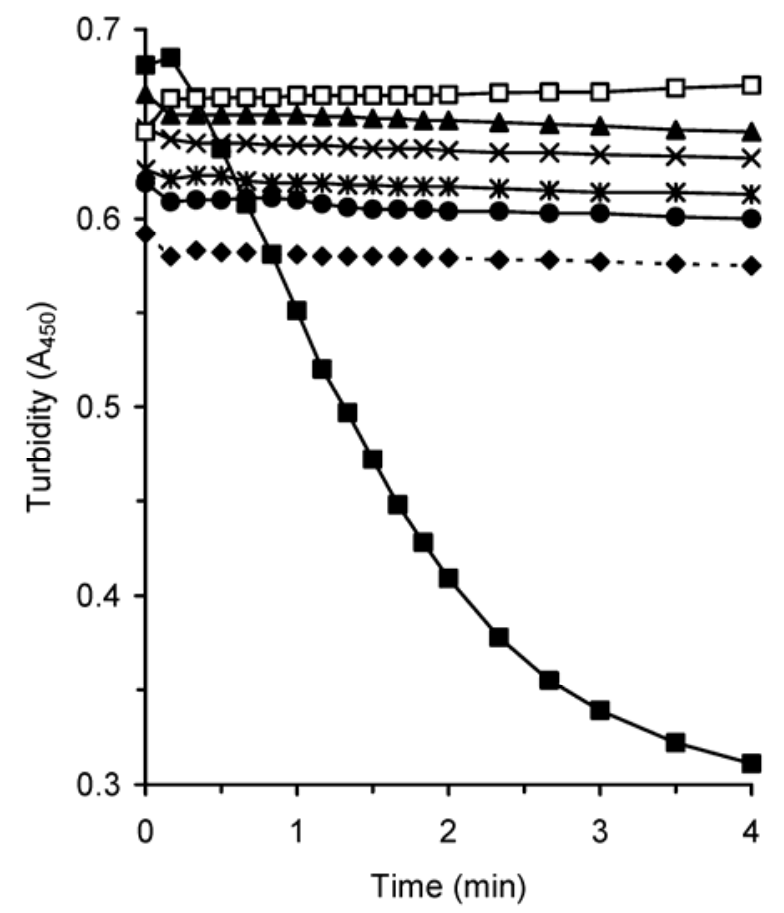

Fig. 2. Photometrical assay for determination of muramidase activity. The absorbance at $450 \mathrm{~nm}$ was monitored in a photometer with lyophilized bacteria and $\phi E a 1 h$ lysozyme. Ea1/79 cells were incubated with untreated M15(pREP4, pQE-lyz1) cell lysate (ם, solid line) and with preparations boiled for $5,15,30$, and $60 \mathrm{~min}(\boldsymbol{\Lambda}, \times, *$, and $\boldsymbol{O}$, respectively). Untreated M15(pREP4, pQE-30) cell lysate ( $\bullet$, dotted line) was used as negative control. Lyophilized Micrococcus luteus cells were incubated with untreated M15(pREP4, pQE-lyz1) cell lysate ( $\square$, solid line). 
tive (Table 2). The most likely explanation is inactivation of the $\phi E a 1 \mathrm{~h}$ lysozyme by neomycin phosphotransferase encoded by nptI or nptII. Expression of a phosphotransferase in Escherichia coli strain HB101(pRK2013::Tn7) from transposon Tn7, which phosphorylates streptomycin, did not affect the lysozyme activity.

Apart from Erwinia amylovora, two related Asian pear pathogens (E. pyrifoliae strain Ep1/96 and a Japanese Erwinia strain), P. agglomerans, E. carotovora subsp. atroseptica, and Escherichia coli strains were sensitive to the viral lysozyme. An E. coli strain with plasmid pREP4 was insensitive to the lysozyme, similar to the kanamycin-resistant Erwinia amylovora strains in contrast to wild-type strains or other bacterial strains lacking kanamycin resistance (Table 2).

Comparison of $\phi$ Ea1h lysozyme and T4 lysozyme. Cell lysates with T4 lysozyme were screened for antibacterial activity by
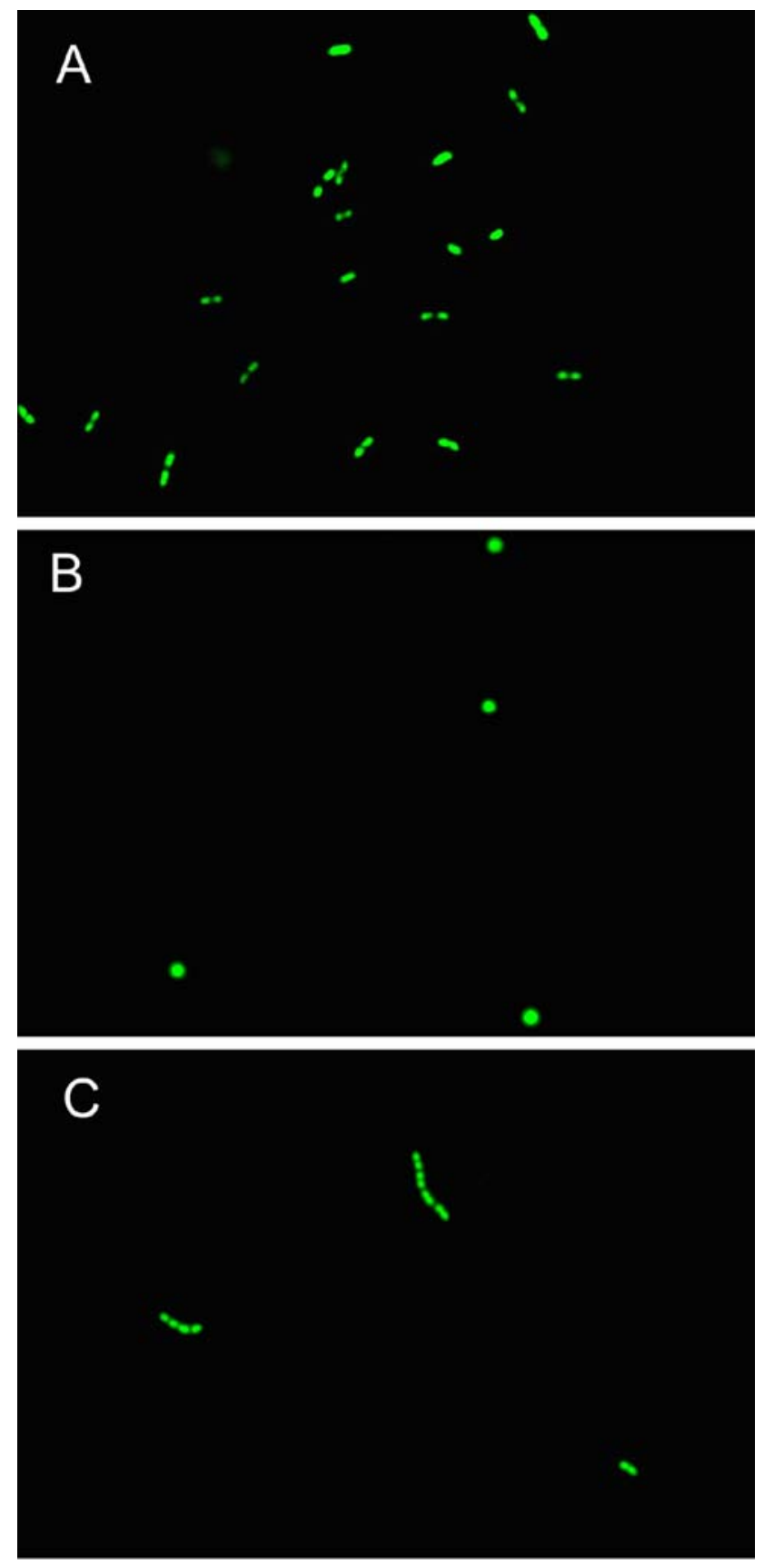

Fig. 3. Fluorescence microscopy of Erwinia amylovora cells stained with the LIVE/DEAD BacLight kit. A, Cells were incubated with M15(pREP4, pQE30) cell lysate as a negative control. The other cells were treated with $\mathbf{B}$, native lysozyme or $\mathbf{C}$, heat-denatured lysozyme. All cells showed green color indicating viable cells. counting CFU, and a clear inhibitory effect with a $10^{5}$-fold reduction of the cell titer was detected against M. luteus (Fig. 6A). No effect was observed on cell viability of E. amylovora. On the other hand, the extract containing $\phi E a 1 h$ lysozyme showed a strong bactericidal effect for E. amylovora, with a 1,000-fold reduction of the cell titer and produced a 100-fold inhibition with $M$. luteus cells (Fig. 6B). The results indicate a divergent host spectrum of $\mathrm{T} 4$ and $\phi E a 1 h$ lysozyme. In these assays, the T4

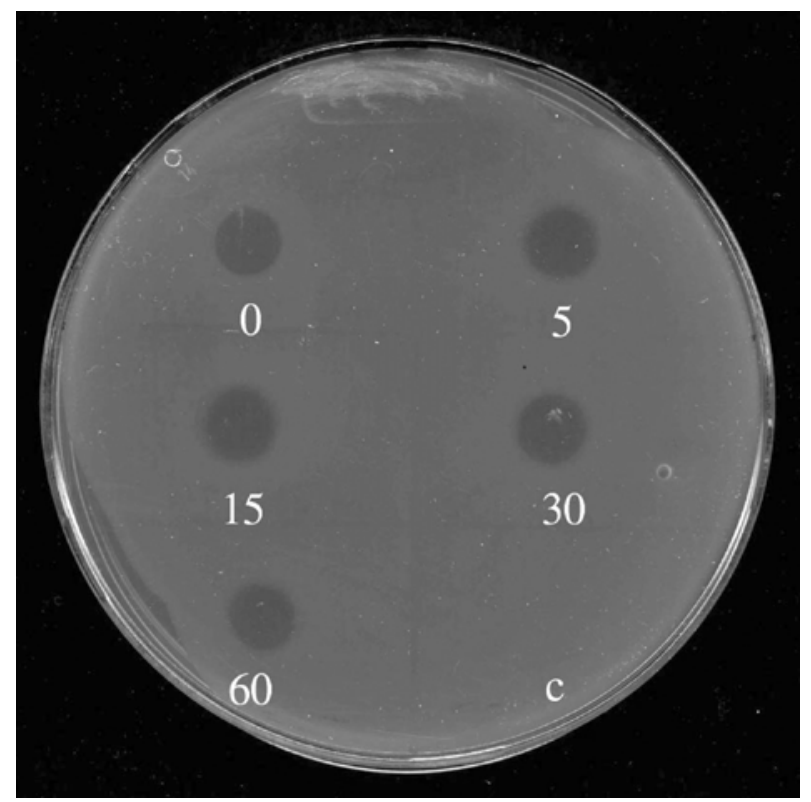

Fig. 4. Agar plate assay to determine the antibacterial activity of heatdenatured $\phi E a 1 h$ lysozyme. Cell lysate of M15(pREP4, pQE-lyz1) was incubated for $5,15,30$, and $60 \mathrm{~min}$ at $100^{\circ} \mathrm{C}$ (numbers in graph) and tested in a plate assay with Ea1/79 as indicator strain. An untreated cell lysate ("0") was applied as a positive control and a cell lysate of strain M15(pREP4; pQE30), heat denatured for $30 \mathrm{~min}$ ("c"), was applied as a negative control.

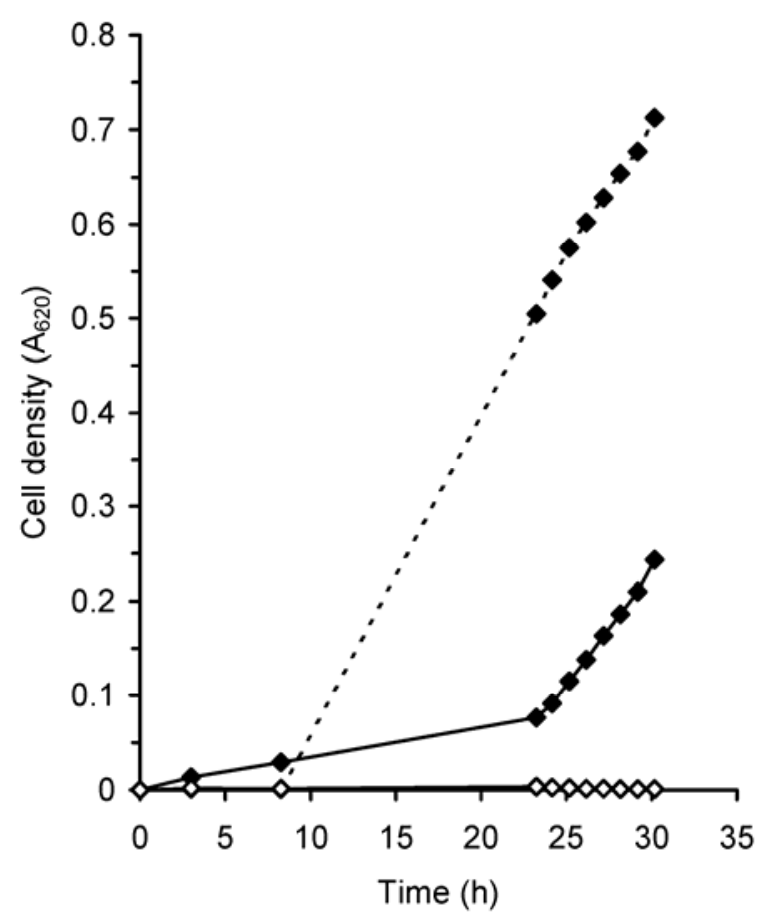

Fig. 5. Microtiter-plate assay with Ea1/79Sm as indicator strain. The same amount of protein $(320 \mu \mathrm{g})$ from native $(\bullet)$ and heat-denatured cell extract $(\diamond)$ with lysozyme was added to the indicator cells. Ea1/79Sm with the addition of the same volume of medium was used as a negative control (dotted line). 
lysozyme had a strong inhibitory effect for a gram-positive bacterium, whereas the $\phi$ Ea1h lysozyme conferred a 10 -fold stronger antibacterial activity against the gram-negative bacterium E. amylovora.

Assays with pear and potato slices. Potato slices and immature pear slices were soaked in cell extracts with $\phi \mathrm{Ea} 1 \mathrm{~h}$ and T4

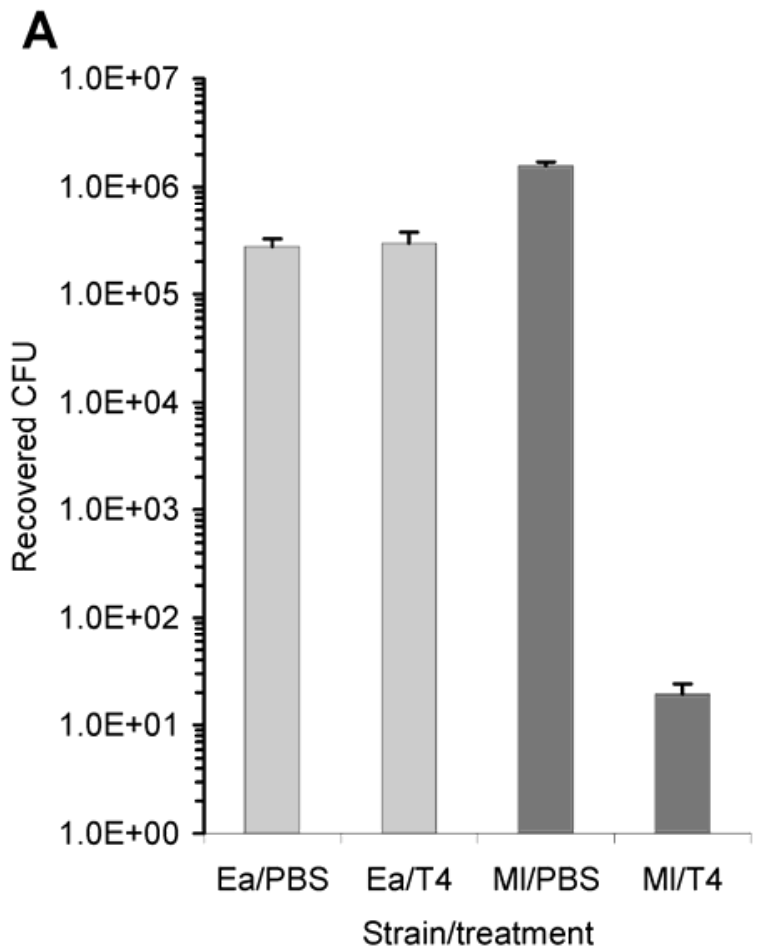

B

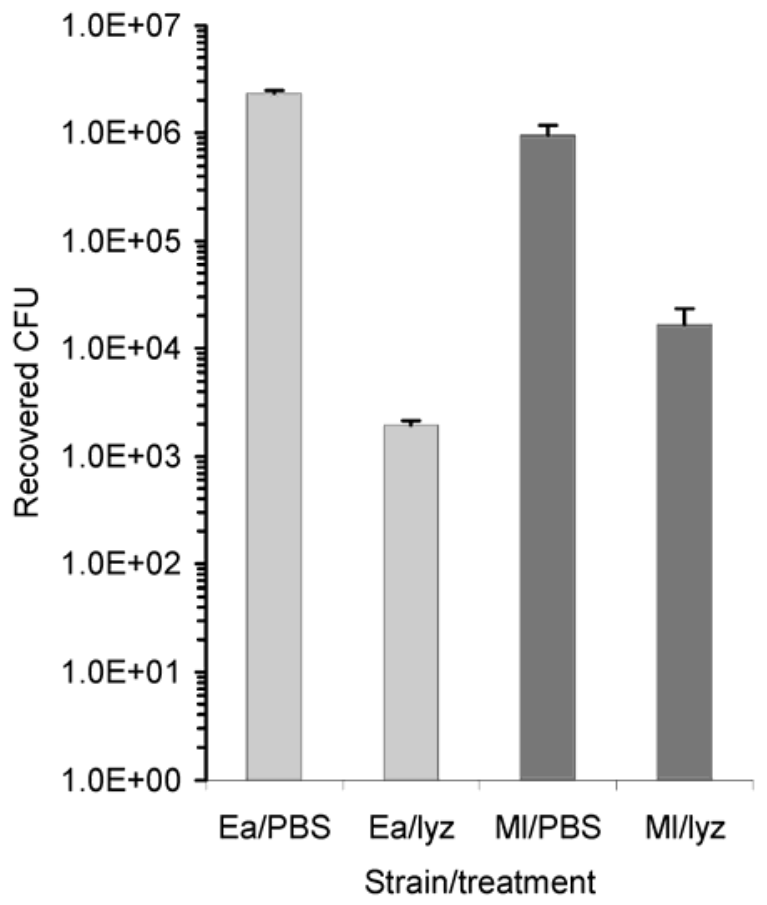

Fig. 6. Viable count plating after treatment of Erwinia amylovora and Micrococcus luteus cells with lysozyme. A, Indicator strains Ea1/79 (Ea) and M. luteus (Ml) were incubated with the same amount $(36 \mu \mathrm{g})$ of T4 lysozyme extracts (T4) per assay and plated on agar; after 2 to 3 days, the colonies were counted. B, Indicator strains were incubated with the same amount $(300 \mu \mathrm{g})$ of $\phi$ Ea1h-lysozyme extracts (lyz) per assay, and processed as in A. The cells were incubated in $0.1 \times$ phosphate buffered saline as the negative control. The standard errors of the mean from three assays are indicated. Both lysozyme extracts were optimized before for inhibition of M. luteus. lysozyme to compare the antibacterial effect of both proteins (Fig. 7). The pear slices were inoculated with E. amylovora strain Ea1/79 by applying from $5 \times 10^{4}$ to $5 \times 10^{1} \mathrm{CFU} /$ slice. The potato slices were inoculated with E. carotovora subsp. atroseptica strain Eca185 by applying $5 \times 10^{7}$ and $5 \times 10^{6} \mathrm{CFU} /$ slice. A high cell number was necessary for the soft rot Erwinia strains to form

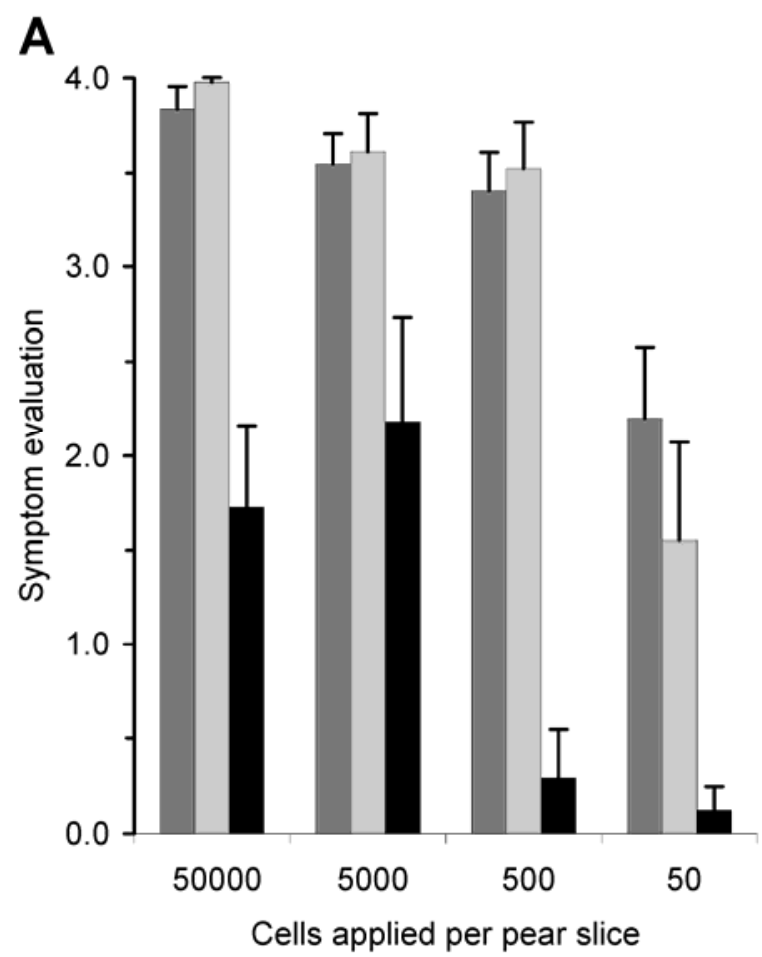

B

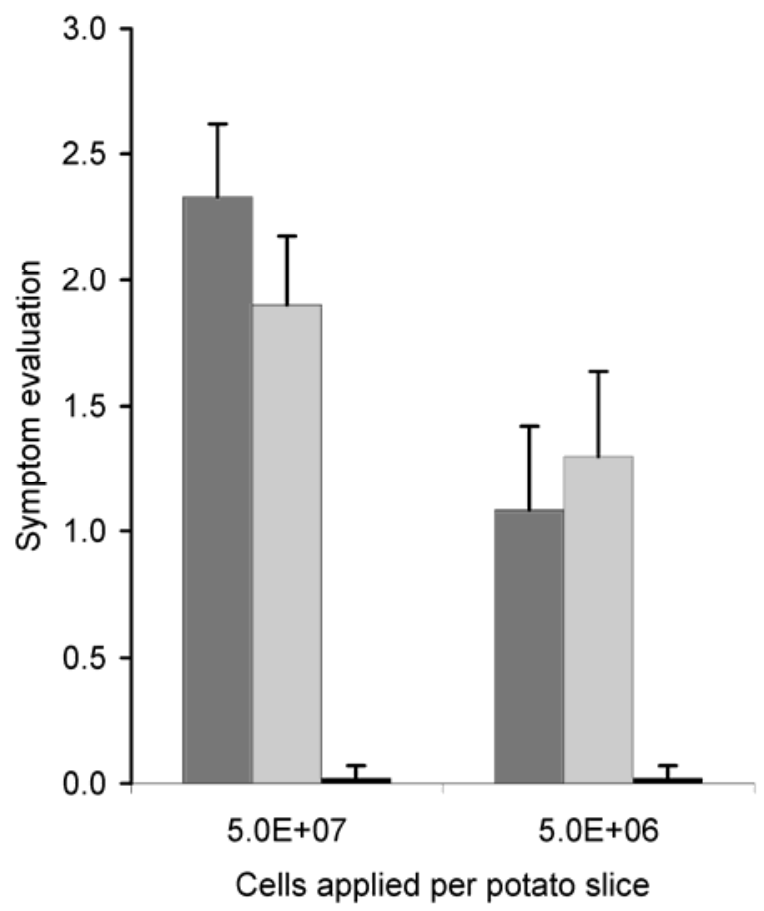

Fig. 7. Virulence assays with pear and potato slices. The ability of cell extracts with T4 lysozyme (bars with intermediate color) and $\phi \mathrm{Ea} 1 \mathrm{~h}$ lysozyme (dark bars) to suppress symptom formation of $\mathbf{A}$, Ea1/79 on pear slices and $\mathbf{B}$, Eca185 on potato slices was determined. For negative control, cell lysate of M15(pREP4, pQE-30) was applied to pear and potato slices (light bars). The data were derived from sets of experiments with 22 and 5 pear slices as well as 12 potato slices. The standard errors of the mean are indicated by lines above the bars. 
symptoms, whereas the fire blight pathogen still produced symptoms at low cell densities applied. Pear slices treated with $\phi E a 1 \mathrm{~h}$ lysozyme showed reduced symptom formation. A weak effect was found for T4 lysozyme at the lowest inoculum density, but none when high amounts of E. amylovora cells were applied to pear slices. In the case of potato slices inoculated with the E. carotovora subsp. atroseptica strain Eca185, no symptoms were observed for slices soaked in cell lysates containing $\phi E a 1 \mathrm{~h}$ lysozyme. These results confirm the survival assays by colony counting that the $\phi \mathrm{Ea} 1 \mathrm{~h}$ and the T4 lysozyme have different spectra of bacterial inhibition and that the T4 lysozyme did not significantly affect the growth of gram-negative bacteria such as E. amylovora and E. carotovora subsp. atroseptica (Fig. 7).

\section{DISCUSSION}

In the life cycle of bacteriophages, lysis of the host cells is a common event. Often, pore-forming proteins such as holins guide lytic proteins from the inside of the cells to the periplasm, where the lysozyme degrades the peptidoglycan layer, resulting in a cell burst (31). For the investigated $\phi E a 1 h$ lysozyme, all tested gramnegative bacteria were sensitive, with the exception of those expressing kanamycin resistance. The neomycin phosphotransferase, responsible for bacterial resistance, phosphorylates a hydroxyl-group of kanamycin and inactivates the antibiotic (29). It is possible that the enzyme also is able to complex or modify and, thereby, detoxify the $\phi E a 1 \mathrm{~h}$ lysozyme in part. The presence of both the kanamycin resistance gene and kanamycin played an important role in the expression of active $\phi E a 1 \mathrm{~h}$ lysozyme. Only Escherichia coli cells carrying the resistance gene and cultured in the presence of the antibiotic were able to produce the gene product in detectable amounts (19). This property can be contributed to partial inactivation of the enzyme after cytosolic expression and to an enhanced resistance of the cells against a lysozyme attack from the outside. It was not possible to detect significant amounts of lysozyme in cell extracts; therefore, the host cells may die early after onset of lyz-gene expression.

The results of this study demonstrate that the antibacterial activity of $\phi E a 1 h$ lysozyme is independent of its enzymatic function as has been previously shown for other lysozymes (14-16). The enzymatic activity cleaves the peptidoglycan layer in the bacterial cell wall, and it was assumed for a long time to be responsible for the antibacterial effect. The peptidoglycan layer of gram-negative bacteria is protected by the outer membrane and is not as easily accessible as for gram-positive bacteria. Therefore, the antibacterial activity of $\phi$ Ea1h lysozyme against gram-negative bacteria such as Erwinia amylovora and E. carotovora subsp. atroseptica might not depend on the muramidase activity. Heatdenaturation of lysozyme is associated with the loss of the native conformation of the protein, but did not affect the antibacterial action. Denatured HEW lysozyme exhibited bactericidal activity against gram-negative and gram-positive bacteria, while the native protein was effective mainly against gram-positive bacteria (13). Ibrahim et al. $(14,15)$ found a correlation between the degree of heat denaturation of HEW lysozyme, the increased hydrophobicity of the protein, and the enhanced antibacterial activity against Escherichia coli. In parallel, the heat-denatured lysozyme showed a high binding ability to membranes of gram-negative bacteria, and permeabilized liposomal membranes made from E. coli cells. For HEW lysozyme, it also was demonstrated by site-directed mutagenesis of the catalytic residue that the antibacterial activity is independent of the catalytic protein function (16).

The microtiter assays showed a high toxic effect to bacteria for the heat-denatured lysozyme. When E. coli strain M15(pREP4, pQE-lyz1) was induced, spheroplasts were formed by enzymatic cleavage of the peptidoglycan layer, and a loss of turbidity was due to membrane disruption by $\phi \mathrm{Ea} 1 \mathrm{~h}$ lysozyme. In that case, the lysozyme can act from inside the cell as well as from outside when the first cells become leaky and the protein is released to the environment. Nonenzymatic inactivation may involve disruption of the bacterial membrane, a mechanism described before for gram-positive bacteria (23) and E. coli (8).

In this study, we also compared the effect of $\phi$ Ea1h lysozyme with T4 lysozyme on viability of Erwinia amylovora cells. In agreement with data of de Vries et al. (6), T4-lysozyme has a $10^{5}$ fold higher inhibitory activity for the gram-positive $M$. luteus compared with the gram-negative E. amylovora (Fig. 6). As shown, $\phi E a 1$ h lysozyme is 10 -fold more efficient against $E$. amylovora compared with M. luteus. Combining these data, it can be estimated that $\phi E a 1 \mathrm{~h}$ lysozyme is at least one million-fold more active against E. amylovora than the T4 lysozyme. Nevertheless, the lysozyme gene of Escherichia coli phage T4 was used in transgenic potato lines to enhance resistance against the soft rot pathogen Erwinia carotovora (7). It also was introduced into apple, slightly increasing fire blight resistance $(10,20)$. Expression of the phage $\phi E a 1 h$ lysozyme gene in plants could significantly increase resistance against pathogenic bacteria. The application of the protein to plant surfaces such as flowers should diminish bacterial colonization and pathogen invasion.

\section{LITERATURE CITED}

1. Bereswill, S., Jock, S., Aldridge, P., Janse, J. D., and Geider, K. 1997. Molecular characterization of natural Erwinia amylovora strains deficient in levan synthesis. Physiol. Mol. Plant Pathol. 51:215-225.

2. Brisset, M. N., Cesbron, S., Thomson, S. V., and Paulin, J. P. 2000. Acibenzolar-S-methyl induces the accumulation of defence-related enzymes in apple and protects from fire blight. Eur. J. Plant Pathol. 106:529-536.

3. Bubab, T., Foldes, L., Kormany, A., Hauptmann, S., Stammler, G., and Rademacher, W. 2003. Prohexadione-Ca in apple trees: Control of shoot growth and reduction of fire blight incidence in blossoms and shoots. J. Appl. Bot.-Angew. Bot. 77:95-102.

4. Bugert, P., and Geider, K. 1995. Molecular analysis of the ams-operon required for exopolysaccharide synthesis of Erwinia amylovora. Mol. Microbiol. 15:917-933.

5. Carlsson, A., Engström, P., Palva, E. T., and Bennich, H. 1991. Attacin, an antibacterial protein from Hyalophora cecropia, inhibits synthesis of outer membrane proteins in Escherichia coli by interfering with omp gene transcription. Infect. Immun. 59:3040-3045.

6. De Vries, J., Harms, K., Broer, I., Kriete, G., Mahn, A., Düring, K., and Wackernagel, W. 1999. The bacteriolytic activity in transgenic potatoes expressing a chimeric T4 lysozyme gene and the effect of T4 lysozyme on soil- and phytopathogenic bacteria. Syst. Appl. Microbiol. 22:280-286.

7. Düring, K., Porsch, P., Fladung, M., and Lörz, H. 1993. Transgenic potato plants resistant to the phytopathogenic bacterium Erwinia carotovora. Plant J. 3:587-598.

8. Düring, K., Porsch, P., Mahn, A., Brinkmann, O., and Gieffers, W. 1999. The non-enzymatic microbicidal activity of lysozymes. FEBS Lett. 449:93-100.

9. Falkenstein, H., Belleman, P., Walter, S., Zeller, W., and Geider, K. 1988. Identification of Erwinia amylovora, the fire blight pathogen, by colony hybridization with DNA from plasmid pEA29. Appl. Environ. Microbiol. 54:2798-2802

10. Hanke, V., Düring, K., Norelli, J. L., and Aldwinckle, H. S. 1998. Transformation of apple cultivars with T4-lysozyme-gene to increase fire blight resistance. Acta Hortic. 489:253-256.

11. Hanke, V., Geider, K., and Richter, K. 2003. Transgenic apple plants expressing viral EPS-depolymerase: Evaluation of resistance to the phytopathogenic bacterium Erwinia amylovora. Pages 153-157 in: Plant Biotechnology: 2002 and Beyond. I. K. Vasil, ed. Kluwer Academic Publishers, Dordrecht, The Netherlands.

12. Hartung, J. S., Fulbright, D. W., and Klos, E. J. 1988. Cloning of a bacteriophage polysaccharide depolymerase gene and its expression in Erwinia amylovora. Mol. Plant-Microbe Interact. 1:87-93.

13. Ibrahim, H. R. 1998. On the novel catalytically-independent antimicrobial function of hen egg-white lysozyme: A conformation-dependent activity. Nahrung 42:187-193.

14. Ibrahim, H. R., Higashiguchi, S., Juneja, L. R., Kim, M., and Yamamoto, T. 1996. A structural phase of heat-denatured lysozyme with novel antimicrobial action. J. Agric. Food Chem. 44:1416-1423.

15. Ibrahim, H. R., Higashiguchi, S., Koketsu, M., Juneja, L. R., Kim, M., Yamamoto, T., Sugimoto, Y., and Aoki, T. 1996. Partially unfolded 
lysozyme at neutral $\mathrm{pH}$ agglutinates and kills gram-negative and grampositive bacteria through membrane damage mechanism. J. Agric. Food Chem. 44:3799-3806.

16. Ibrahim, H. R., Matsuzaki, T., and Aoki, T. 2001. Genetic evidence that antibacterial activity of lysozyme is independent of its catalytic function. FEBS Lett. 506:27-32.

17. Kim, W.-S., and Geider, K. 2000. Characterization of a viral EPSdepolymerase, a potential tool for control of fire blight. Phytopathology 90:1263-1268.

18. Kim, W.-S., Hildebrand, M., Jock, S., and Geider, K. 2001. Molecular comparison of pathogenic bacteria from pear trees in Japan and the fire blight pathogen Erwinia amylovora. Microbiology 147:2951-2959.

19. Kim, W.-S., Salm, H., and Geider, K. 2004. Expression of bacteriophage $\phi$ Ea1h-lysozyme in Escherichia coli and its activity in growth inhibition of Erwinia amylovora. Microbiology 150:2707-2714.

20. Ko, K. S., Norelli, J. L., Reynoird, J. P., Aldwinckle, H. S., and Brown, S. K. 2002. T4 lysozyme and attacin genes enhance resistance of transgenic 'Galaxy' apple against Erwinia amylovora. J. Am. Soc. Hortic. Sci. 127:515-519.

21. Lindow, S. E., McGourty, G., and Elkins, R. 1996. Interaction of antibiotics with Pseudomonas fluorescens strain A506 in the control of fire blight and frost injury to pear. Phytopathology 86:841-848.

22. Lowry, O. H., Rosebrough, N. J., Farr, A. L., and Randall, R. J. 1951. Protein measurement with folin phenol reagent. J. Biol. Chem. 193:265-275.

23. Masschalck, B., Deckers, D., and Michiels, C. W. 2002. Lytic and nonlytic mechanism of inactivation of gram-positive bacteria by lysozyme under atmospheric and high hydrostatic pressure. J. Food Prot. 65:19161923.

24. Momol, M. T., Norelli, J. L., and Aldwinckle, H. S. 1996. Field evaluation of fire blight resistance of an attacin E-transgenic M.7 apple rootstock. (Abstr.) Phytopathology 86:S92.

25. Porsch, P., Janke, A., and Düring, K. 1998. A plant transformation vector with a minimal T-DNA II. Irregular integration patterns of the T-DNA in the plant genome. Plant Mol. Biol. 37:581-585.

26. Rhim, S.-L., Völksch, B., Gardan, L., Paulin, J.-P., Langlotz, C., Kim, W.S., and Geider, K. 1999. An Erwinia species, different from Erwinia amylovora, causes a necrotic disease of Asian pear trees. Plant Pathol. 48:514-520.

27. Schmidt, C., Velleman, M., and Arber, W. 1996. Three functions of bacteriophage P1 involved in cell lysis. J. Bacteriol. 178:1099-1104.

28. Schnabel, E. L., and Jones, A. L. 2001. Isolation and characterization of five Erwinia amylovora bacteriophages and assessment of phage resistance in strains of Erwinia amylovora. Appl. Environ. Microbiol. 67: 59-64.

29. Shaw, K. J., Rather, P. N., Hare, R. S., and Miller, G. H. 1993. Molecular genetics of aminoglycoside resistance genes and familial relationships of the aminoglycoside-modifying enzymes. Microbiol. Rev. 57:138-163.

30. Vanneste, J., ed. 2000. Fire Blight: The Disease and Its Causative Agent Erwinia amylovora, CABI Publishing. Wallingford Oxon/UK-New York.

31. Young, R. 1992. Bacteriophage lysis: Mechanism and regulation. Microbiol. Rev. 56:430-481. 